\title{
Seat-interface pressure: A pilot study of the relationship to gender, body mass index, and seating position
}

Stinson, M., Porter-Armstrong, A., \& Eakin, P. (2003). Seat-interface pressure: A pilot study of the relationship to gender, body mass index, and seating position. Archives of Physical Medicine and Rehabilitation, 84(3), 405409. https://doi.org/10.1053/apmr.2003.50011

Link to publication record in Ulster University Research Portal

Published in:

Archives of Physical Medicine and Rehabilitation

Publication Status:

Published (in print/issue): 01/03/2003

DOI:

10.1053/apmr.2003.50011

\section{Document Version}

Publisher's PDF, also known as Version of record

\section{General rights}

Copyright for the publications made accessible via Ulster University's Research Portal is retained by the author(s) and / or other copyright owners and it is a condition of accessing these publications that users recognise and abide by the legal requirements associated with these rights.

\section{Take down policy}

The Research Portal is Ulster University's institutional repository that provides access to Ulster's research outputs. Every effort has been made to ensure that content in the Research Portal does not infringe any person's rights, or applicable UK laws. If you discover content in the Research Portal that you believe breaches copyright or violates any law, please contact pure-support@ulster.ac.uk. 


\title{
Seat-Interface Pressure: A Pilot Study of the Relationship to Gender, Body Mass Index, and Seating Position
}

\author{
May D. Stinson, MSc, Alison Porter-Armstrong, DPhil, Pamela Eakin, DPhil
}

ABSTRACT. Stinson MD, Porter-Armstrong A, Eakin P. Seat-interface pressure: a pilot study of the relationship to gender, body mass index, and seating position. Arch Phys Med Rehabil 2003;84:405-9.

Objectives: To investigate the relationship between interface pressure and gender, body mass index (BMI), and seating positions, and to evaluate the implications for clinical practice.

Design: Group design.

Setting: Pressure mapping laboratory.

Participants: Sixty-three student volunteers (44 women, 19 men; mean age, 22.2 $\pm 5.1 \mathrm{y}$ ).

Interventions: Seated-interface pressure was measured using the Force Sensing Array pressure mapping system. Seating positions used included recline $\left(10^{\circ}, 20^{\circ}, 30^{\circ}\right)$, foot support, and foot elevation.

Main Outcome Measures: Interface pressure in the form of both average pressure (mean of the pressure sensor values) and maximum pressure (highest individual sensor value).

Results: Both average and maximum pressures were independent of gender, while average pressure had a significant positive correlation with BMI $(r=.381, \alpha=.01$ level). Recline of the chair by $30^{\circ}$ significantly reduced average pressure $(P<.001)$, whereas recline by $10^{\circ}$ or $20^{\circ}$ had no significant effect. Recline by $10^{\circ}, 20^{\circ}$, and $30^{\circ}$ did not significantly alter maximum pressure. Elevation of the feet on a footstool reduced average pressure to a level approaching statistical significance, while supporting participants' feet versus leaving them unsupported significantly increased average pressure at a $0^{\circ}, 10^{\circ}$, $20^{\circ}$, and $30^{\circ}$ recline $(P<.01)$ and maximum pressure at $0^{\circ}, 10^{\circ}$ $(P<.01)$, and $30^{\circ}(P<.05)$.

Conclusions: Elevating clients' feet and reclining their chair by $30^{\circ}$ reduced interface pressure and the associated risk of pressure ulcer development. Additional research is required, however, to replicate this study with participants at increased risk of pressure ulcer development.

Key Words: Pressure; Pressure ulcer; Rehabilitation.

(C) 2003 by the American Congress of Rehabilitation Medicine and the American Academy of Physical Medicine and Rehabilitation

$\mathbf{P}$ RESSURE ULCERS PRESENT a major problem for the National Health Service, costing up to $£ 755$ million per annum in England, ${ }^{1}$ as well as immense personal cost to the individuals experiencing them. Many factors contribute to their

From the Rehabilitation Sciences Research Group, University of Ulster, Northern Ireland.

Supported by a Millennial Studentship, from the Department of Higher and Further Education, Training and Employment and the University of Ulster.

No commercial party having a direct financial interest in the results of the research supporting this article has or will confer a benefit upon the author(s) or upon any organization with which the author(s) is/are associated.

Reprint requests to May D. Stinson, MSc, Rehabilitation Sciences Research Group, Block 50K23, University of Ulster, Shore Rd, Newtownabbey, Co. Antrim, BT37 OQB, Northern Ireland, e-mail: maystinson@hotmail.com.

0003-9993/03/8403-7390\$30.00/0

doi:10.1053/apmr.2003.50011 development. Reduced mobility is a significant risk factor. ${ }^{2}$ Any condition or disease that impairs movement will increase the risk of developing pressure ulcers, ${ }^{3}$ including pain, excessive sedation, psychiatric illness, orthopedic injury, and neurologic disease. ${ }^{4}$ Sensory impairment may also contribute to pressure ulcer development, for example, in patients with stroke, ${ }^{5}$ diabetes, or spinal injuries. ${ }^{6}$ Reduced sensation leads to insensitivity to pain or discomfort and results in decreased or absent stimulus to move in order to relieve pressure. ${ }^{6}$

Age is another contributing factor, with elderly people having increased susceptibility due to reduced skin elasticity, loss of subcutaneous fat, muscle atrophy, reduced cell proliferation, and collagen disposition. ${ }^{7}$ Elderly people may also experience severely compromised nutrition, ${ }^{8}$ another feature linked to pressure ulcer development. Malnutrition may increase the risk of pressure ulcer development through various pathways, including depletion of lymphocytes and serum proteins, ${ }^{9}$ increased risk of organ failure and serious illness, ${ }^{6}$ and emaciation. ${ }^{2}$ Fecal and urinary incontinence also incur risk toward pressure ulcer development, ${ }^{10,11}$ as well as vascular disease ${ }^{3}$ and any history of pressure ulcers. ${ }^{12}$

Shear, friction, and pressure are important factors involved in pressure ulcer development. Shear occurs when the deep fascia and skeleton move over the skin and upper fascia, resulting in damage to the vascular supply in the subcutaneous tissues. Shearing forces are an integral part of the effect of pressure and occur, for example, when a patient slides down in bed. ${ }^{6}$ No satisfactory method of measuring shear has been developed. ${ }^{13}$ Friction occurs when 2 surfaces move across each other, often causing damage to superficial layers of skin and is frequently because of poor moving and handling techniques. ${ }^{14}$

Although numerous factors are implicated in the development of pressure ulcers, many of which have been outlined previously, the most important is unrelieved pressure..$^{13,15-17}$ Pressure results in compression and possible capillary occlusion and can lead to ischemia if prolonged. ${ }^{6}$ The probability of developing a pressure ulcer is known to increase with the duration and the magnitude of pressure involved, ${ }^{18}$ and this in turn depends on the individual's tissue tolerance. ${ }^{14}$ It is known that both low and high pressures can lead to pressure ulcer development, depending on duration. ${ }^{19}$

Animal studies conducted by Kosiak ${ }^{15}$ in 1959 and Daniel et $\mathrm{al}^{20}$ in 1981 and a human study by Reswick and Rogers ${ }^{21}$ in 1976 described an inverse parabolic relationship between pressure and time. That is, high pressure exerted over a short period of time could lead to deep tissue damage, whereas lower pressures exerted over a longer period of time may result in skin and muscle damage. ${ }^{20}$ It is frequently stated that any load greater than $32 \mathrm{mmHg}$ is harmful because it exceeds capillary pressure, thus causing occlusion. ${ }^{22}$ Sprigle, ${ }^{22}$ however, emphasizes that this value is a misinterpretation of a 1930 study by Landis $^{23}$ and that no specific threshold has yet been identified at which pressure can be considered harmful. Indeed, no controlled investigations have been carried out on pressure and the application time needed to cause pressure ulcers. ${ }^{24}$ The relationship between interface (or contact) pressure, and pressure 
Table 1: Gender, Height, Weight, and BMI of Participants

\begin{tabular}{lccc}
\hline \multicolumn{1}{c}{ Participants } & Height $(\mathrm{cm})$ & Weight $(\mathrm{kg})$ & $\mathrm{BMI}\left(\mathrm{kg} / \mathrm{m}^{2}\right)$ \\
\hline Men $(\mathrm{n}=19)$ & $179.63 \pm 5.24$ & $61.00 \pm 10.37$ & $20.29-31.00$ \\
Women $(\mathrm{n}=44)$ & $164.63 \pm 5.63$ & $48.50 \pm 7.59$ & $17.00-27.84$
\end{tabular}

NOTE. Values are mean \pm SD or range.

ulcer prevention, including such variables as acceptable time and pressure limits, requires further research. ${ }^{24}$

Nevertheless, it is accepted that pressure monitoring at the interface between the body and support surface is important in the assessment of tissue viability ${ }^{25}$ and in the selection of appropriate pressure-relieving cushions. ${ }^{26}$ Recent work by Geyer et $\mathrm{al}^{27}$ has shown that higher interface pressures are associated with higher incidence of pressure ulcers in elderly, at-risk clients. ${ }^{27}$ Interface-pressure measurement may be achieved through pressure mapping techniques. One such pressure mapping system, the Force Sensing Array ${ }^{\mathrm{a}}$ used in our study, has been favorably described by several authors. ${ }^{28-30}$

Measurements from pressure mapping are subject to the influence of many variables. Previous research studies have investigated the relationship between interface pressure and variables such as body mass index (BMI) and seating position $^{1,31,32}$ by using systems other than the Force Sensing Array. Our study attempted to examine the effect of such variables on interface pressure by using the Force Sensing Array system. Furthermore, because several researchers have included male gender as a risk factor for pressure ulcer development, ${ }^{11,33}$ the relationship between gender and interface pressure was also considered.

The purpose of this pilot study was to investigate whether pressure in seating was related to gender or BMI. In addition, this study examined whether changes in seating position (foot elevation; foot support; recline by $10^{\circ}, 20^{\circ}, 30^{\circ}$ ) significantly altered interface pressure readings.

\section{METHODS}

\section{Participants}

This pilot study was performed with 63 student volunteers (44 women, 19 men), whose mean age \pm standard deviation (SD) was $22.2 \pm 5.08$ years, mean height was $69.2 \pm 8.79 \mathrm{~cm}$, and mean weight was $67.0 \pm 12.4 \mathrm{~kg}$. Further details regarding the respective height, weight, and BMI of the participants are included in table 1 . The criteria for selection were being able-bodied, aged between 18 and 40 years, and giving written informed consent. Any volunteers fulfilling these criteria were included.

\section{Instrumentation}

The Force Sensing Array is a clinical tool used in the assessment of pressure distribution at an interface, that is, between subject and seat. It is comprised of a pressure-sensing mat connected by an interface module to a computer. Data computed from the sensors are presented in various forms, including a color-coded map, 3-dimensional grid, and numeric pressure values.

\section{Procedure}

Before the study began, the seat pressure mat was calibrated according to the manufacturer's product manual. The same calibration was used throughout the study to maximize comparability of results. The study took place over a 10-day period. Before pressure measurements were made, the height and weight of each participant was measured and recorded, and BMI was subsequently calculated $\left(\mathrm{kg} / \mathrm{m}^{2}\right)$.

Interface-pressure readings recorded included both average and maximum pressures, which may be defined as follows: average pressure is the measure of the mean of the sensor values, and maximum pressure is the highest individual sensor.

Procedure for pressure measurement in relation to recline of chair and foot support. During assessment, the pressure mat was placed between the participant and the support surface, an armchair with seat height of $51 \mathrm{~cm}$ and a manually adjustable ratchet back which reclined by $10^{\circ}, 20^{\circ}$, and $30^{\circ}$ from the neutral position. The chair surface was made from upholstered foam (grade R650F on seat, grade $400 \mathrm{H}$ on back). Participants were seated in a relaxed position with arms placed on the armrests and at $90^{\circ}$ of flexion at hips, knees, and ankles. In cases in which participants' feet did not reach the floor, feet were supported on blocks to achieve the above posture. Pressure readings were taken at a $0^{\circ}, 10^{\circ}, 20^{\circ}$, and $30^{\circ}$ recline. The comparative effects on interface pressure between supporting participants' feet on blocks and leaving them unsupported was investigated by recording another set of pressure readings at a $0^{\circ}, 10^{\circ}, 20^{\circ}$, and $30^{\circ}$ recline with feet unsupported $(n=45)$.

Procedure for pressure measurement in relation to foot elevation. Pressure was recorded with the participants' feet elevated on a $30 \mathrm{~cm}$ high footstool, legs straight, hips at $90^{\circ}$ of flexion, with the chair back at a $0^{\circ}$ recline $(n=59)$. Four participants were excluded from this part of the study because of incomplete data collection.

\section{Statistical Analysis}

Statistical analysis was performed by using SPSS. ${ }^{\text {b }}$ The Student $t$ test was applied to differences in average and maximum pressures with gender, foot support, foot elevation, and various degrees of seat back recline. The Pearson correlation coefficient was used to examine the correlation between interface pressure and the following parameters: height, weight, and BMI.

\section{RESULTS}

\section{Gender and Pressure}

No significant difference was found in average pressure or maximum pressure between male and female participants (table 2).

\section{BMI and Pressure}

No significant correlation was found between height or weight and average pressure. However, a significant correlation $(r=.381, P<.01)$ between BMI and average pressure was identified. No significant correlation was found between height, weight, or BMI and maximum pressure.

\section{Recline and Pressure}

No significant differences in maximum pressure were found between a $0^{\circ}$ recline (neutral position) and a $10^{\circ}, 20^{\circ}$, or $30^{\circ}$ recline of the chair back (table 3 ). No significant difference in average pressure was found between conditions of a $0^{\circ}$ recline

Table 2: Average and Maximum Pressure in Relation to Gender

\begin{tabular}{lcc}
\hline & $\begin{array}{c}\text { \% Difference Between } \\
\text { Men and Women }\end{array}$ & Significance $(t$ Test) \\
\hline Average pressure & 3.399 & .302 \\
Maximum pressure & 2.073 & .641 \\
\hline
\end{tabular}


Table 3: Maximum Pressure in Relation to Recline of Chair Back

\begin{tabular}{ccc}
\hline $\begin{array}{c}\text { Recline of } \\
\text { Chair Back }\end{array}$ & $\begin{array}{c}\text { \% Change in Mean Maximum } \\
\text { Pressure vs } 0^{\circ} \text { Recline }\end{array}$ & $\begin{array}{c}\text { Significance } \\
(t \text { Test })\end{array}$ \\
\hline $10^{\circ}$ & 0.000 & 1.000 \\
$20^{\circ}$ & 0.463 & 0.822 \\
$30^{\circ}$ & 1.111 & 0.649
\end{tabular}

and both a $10^{\circ}$ and $20^{\circ}$ recline of chair back. However, a significant reduction in average pressure $(P<.01$ level $)$ was identified between conditions of a $0^{\circ}$ and $30^{\circ}$ recline of chair back (table 4).

\section{Foot Support and Pressure}

A significant increase in average pressure was found by supporting participants' feet at a $0^{\circ}, 10^{\circ}, 20^{\circ}$, and $30^{\circ}$ recline of seat back (table 5). A significant increase in maximum pressure was found by supporting participants' feet at a $0^{\circ}, 10^{\circ}$ $(P<.01$ level $)$, and $30^{\circ}$ recline $(P<.05$ level $)$. No significant difference in maximum pressure was found between not supporting and supporting participants' feet at a $20^{\circ}$ back recline, although pressure still increased (table 6).

\section{Feet Elevation and Pressure}

No significant difference in average pressure was found between not elevating and elevating the participants' feet on a $30 \mathrm{~cm}$ footstool, although the statistical value obtained $(P=.052)$ approached significance (table 7). No significant difference in maximum pressure was found between conditions of elevating and not elevating the participants' feet on a footstool.

\section{DISCUSSION}

The development of pressure ulcers has been linked to multiple risk factors, including reduced mobility, ${ }^{3}$ impaired sensation, ${ }^{5}$ age,${ }^{7}$ malnutrition, ${ }^{9}$ incontinence, ${ }^{10}$ shear, friction, ${ }^{18}$ and pressure. ${ }^{17}$ However, the predominant cause of pressure ulcer development is thought to be high interface pressure. ${ }^{16}$

Results showed that both average and maximum pressures were independent of gender. The latter supported earlier findings by Garber and Krouskop, ${ }^{31}$ although these investigators did not concurrently examine the relationship between average pressure and gender. On the contrary, although some previous studies ${ }^{11,33}$ have described male gender as a risk factor for pressure development, our study provided no link between male gender and increased interface pressure.

A positive correlation was identified between average pressure and BMI, whereas no correlation was evident between average pressure and height or weight. Similar findings, in terms of average pressure increasing as BMI increases, have been outlined by Scott et $\mathrm{al}^{1}$ who, although they also used the Force Sensing Array system, used mattresses rather than chairs as a support surface. Unfortunately, with the data obtained in our study, it was not possible to explore the correlation be-

Table 4: Average Pressure in Relation to Recline of Chair Back

\begin{tabular}{ccc}
\hline $\begin{array}{c}\text { Recline of } \\
\text { Chair Back }\end{array}$ & $\begin{array}{c}\text { \% Change in Mean Average } \\
\text { Pressure vs } 0^{\circ} \text { Recline }\end{array}$ & $\begin{array}{c}\text { Significance } \\
(t \text { Test })\end{array}$ \\
\hline $10^{\circ}$ & -0.296 & .764 \\
$20^{\circ}$ & -2.086 & .057 \\
$30^{\circ}$ & -5.628 & .000 \\
\hline
\end{tabular}

Table 5: Average Pressure Changes Between Supporting and Not Supporting Participants' Feet

\begin{tabular}{ccc}
\hline $\begin{array}{c}\text { Recline of } \\
\text { Chair Back }\end{array}$ & $\begin{array}{c}\text { \% Difference in Average Pressure } \\
\text { Between Not Supporting and } \\
\text { Supporting Feet }\end{array}$ & $\begin{array}{c}\text { Significance } \\
(t \text { Test })\end{array}$ \\
\hline $0^{\circ}$ & 13.913 & .000 \\
$10^{\circ}$ & 6.324 & .000 \\
$20^{\circ}$ & 4.903 & .000 \\
$30^{\circ}$ & 2.793 & .009 \\
\hline
\end{tabular}

tween pressure and specific BMI categories as previously performed by Scott, ${ }^{1}$ because sample sizes were very small when subdivided. This may warrant further investigation.

Reclining the back of the chair from the neutral position did not significantly alter mean average pressure or maximum pressure at either $10^{\circ}$ or $20^{\circ}$. Shields and Cook $^{34}$ had previously found no significant difference in interface pressure between upright and $20^{\circ}$ reclined positions. Recline by $30^{\circ}$ in our study also showed no significant effect on maximum pressure but significantly reduced average pressure $(P<.01)$. The latter may be an important consideration for positioning during seating because intervention to reduce interface pressure will help prevent pressure ulcers. Measurement of sacral interface pressures when assuming a position of a $30^{\circ}$ recline would be necessary to ensure that the potential shift of pressure from the ischial tuberosities does not contribute to sacral pressure ulcer development.

Raising participants' feet on a footstool did not significantly affect average or maximum pressures, although the former approached statistical significance $(P=.052)$, with elevation of the feet resulting in reduced average pressure. Combined with other medical benefits of foot elevation, such as reduction of edema, this position may be advantageous in terms of reducing interface pressure and thus the risk of pressure ulcer development.

Controversy surrounds average and maximum pressures regarding which is the best outcome measure, which should be reported, and which is the best descriptor of interface pressure. As stated, average pressure is the mean of all the sensor values, whereas maximum pressure is the highest individual sensor value. Some studies have focused on reporting maximum pressure and not average pressure ${ }^{17,27,35,36}$; however, these researchers did not include reasons for their choice. Although not specified, this may have been because of the constraints of the technology being used. In a rigorous study by a renowned international researcher, Sprigle et al $^{37}$ reported only average pressure, referring to it as "a very stable measure." Peak (or maximum) pressure was not analyzed in that study because of "the instability of the measure." $37 \mathrm{We}$ concur with Sprigle ${ }^{37}$ that average pressure is a more stable measure and gives a

Table 6: Maximum Pressure Changes Between Supporting and Not Supporting Participants' Feet

\begin{tabular}{ccc}
\hline $\begin{array}{c}\text { Recline of } \\
\text { Chair Back }\end{array}$ & $\begin{array}{c}\text { Pressure Between in Mean Maximum } \\
\text { Supporting Feet }\end{array}$ & \\
\hline $0^{\circ}$ & 21.657 & Significance ( $t$ Test) \\
$10^{\circ}$ & 6.348 & .000 \\
$20^{\circ}$ & 3.803 & .005 \\
$30^{\circ}$ & 4.192 & .100 \\
& & .028 \\
\hline
\end{tabular}


Table 7: Pressure Changes With Elevation of Participants' Feet

\begin{tabular}{lcc}
\hline & $\begin{array}{c}\text { \% Difference Between } \\
\text { Nonelevation and } \\
\text { Elevation of Feet }\end{array}$ & $\begin{array}{c}\text { Significance } \\
(t \text { Test })\end{array}$ \\
\hline Average pressure & -3.093 & .052 \\
Maximum pressure & -0.640 & .809 \\
\hline
\end{tabular}

better overall picture of interface pressure in disabled people than maximum pressure, which is a single sensor value.

Investigations comparing pressure changes between supporting and not supporting participants' feet (when these did not naturally extend to the floor when seated on the given armchair) produced unexpected results. Supporting participants' feet to achieve $90^{\circ}$ of flexion at hips, knees, and ankles significantly increased average pressure at the $0^{\circ}, 10^{\circ}, 20^{\circ}$, and $30^{\circ}$ recline positions $(P<.01)$. Maximum pressure was also significantly increased by supporting the participants' feet at the $0^{\circ}$, $10^{\circ}(P<.01)$, and $30^{\circ}$ recline $(P<.05)$ positions, with the increase occurring at the $20^{\circ}$ recline not being statistically significant. The increase in pressure found in this study when feet were supported (although not elevated) appears contradictory to recent clinical guidelines that advise feet support during seating. ${ }^{38}$ Our findings are also inconsistent with ergonomic guidelines given by Dreyfuss, ${ }^{39}$ who recommended supporting the feet to relieve pressure under the thigh.

\section{CONCLUSION}

Although based on a small sample of healthy subjects, this study has shown some interesting results, namely, that reclining the seat by $30^{\circ}$ and elevating subjects' feet on a footstool reduced average interface pressure. These findings would add to the other advantages facilitated by these positions as mentioned earlier, including the reduction or prevention in edema. It should be noted, however, that such maneuvers may supplement, but should not replace, pressure-relief techniques for people at high risk of developing pressure ulcers.

Laboratory-based studies using healthy populations, such as those described herein, are considered by us to be essential before application with a disabled cohort. ${ }^{40}$ These first-stage investigations require subjects to adopt a number of seating positions, some of which may be shown later to provide less than optimal pressure relief. As opposed to a disabled cohort, healthy subjects can easily adopt the positions required, sustaining little or no discomfort in doing so. Studies such as these provide a focus of direction for second-stage studies with disabled populations and can potentially minimize pain or discomfort by restricting the range of positions under investigation.

The limitations of this pilot study should be considered. These include the use of small samples and able-bodied participants adopting a "perfect" seated position. Caution must be taken before applying the findings of our study to clinical practice, given the differences between able-bodied and disabled populations, because higher interface pressures have been demonstrated with elderly and disabled populations when compared with young healthy subjects. ${ }^{32,41}$

In terms of future research, our pilot study should initially be replicated with a larger group of able-bodied subjects. Areas to be included for further investigation include the correlation between interface pressure and specific BMI categories, the effect of tilt beyond $30^{\circ}$ on interface pressures, and the change in pressure on the sacrum as the subject is reclined. Results from these studies should then be verified within a disabled population before their application in clinical practice.

\section{References}

1. Scott EM, Baker EA, Kelly PJ, Stoddard EJ, Leaper DJ. Measurement of interface pressures in the evaluation of operating theatre mattresses. J Wound Care 1999;8:437-41.

2. Allman RM, Goode PS, Patrick MM, Burst N, Bartolucci AA Pressure ulcer risk factors among hospitalized patients with activity limitation. JAMA 1995;273:865-70.

3. Vohra RK, McCollum CN. Pressure sores. BMJ 1994;309:853-7.

4. Levine JM, Simpson M, McDonald RJ. Pressure sores: a plan for primary care prevention. Geriatrics 1989;44:75-90.

5. Berlowitz DR, Wilking SV. Risk factors for pressure sores: a comparison of cross-sectional and cohort-derived data. J Am Geriatr Soc 1989;37:1043-50.

6. Rycroft-Malone J, McInness E. Pressure ulcer risk assessment and prevention. Clinical practice guidelines. London: RCN; 2000.

7. Simpson A, Bowers K, Weir-Hughes D. Preventative management. In: Pressure sore prevention. London: Whurr Publishers; 1996. p 47-57.

8. Low AW. Prevention of pressure sores in patients with cancer. Oncol Nurs Forum 1990;17:179-84.

9. Waltman NL, Bergstrom N, Armstrong N, Norvell K, Braden B. Nutritional status, pressure sores and mortality in elderly patients with cancer. Oncol Nurs Forum 1991;18:867-73.

10. Bianchetti A, Zanetti O, Rozzini R, Trabucchi M. Risk factors for the development of pressure sores in hospitalized elderly patients: results of a prospective study. Arch Gerontol Geriatr 1993;16:22532.

11. Brandeis GH, Ooi WL, Hossain M, Morris JN, Lipsitz LA. A longitudinal study of risk factors associated with the formation of pressure ulcers in nursing homes. J Am Geriatr Soc 1990;42:38893.

12. Clark M, Watts S. The incidence of pressure sores in a National Health Service Trust hospital during 1991. J Adv Nurs 1994;20: 33-6.

13. Barbenel JC. Pressure management. Prosthet Orthot Int 1991;15: 225-31.

14. Defloor T. The risk of pressure sores: a conceptual scheme. J Clin Nurs 1999;8:206-16.

15. Kosiak M. Etiology and pathology of ischemic ulcers. Arch Phys Med Rehabil 1959;40:62-9.

16. Kosiak M. Prevention and rehabilitation of pressure ulcers. Decubitus 1991;4:60-8

17. Veit N. Advancement in computer technology: a tool to identify seating problems and prevent pressure ulcers. SCI Nurs 1993;10: 99.

18. Defloor T, Gryponck MH. Do pressure relief cushions really relieve pressure? West J Nurs Res 2000;22:335-50.

19. McNally P. The role of the nurse within the multidisciplinary team, in reducing the incidence of pressure sores. Woundcare $1999 ; 2: 28-9$

20. Daniel RK, Priest DL, Wheatley DC. Etiological factors in pressure sores: an experimental model. Arch Phys Med Rehabil 1981; 62:492-8.

21. Reswick J, Rogers J. Experience at Rancho Los Amigos Hospital with devices and techniques to prevent pressure sores. In: Kenedi RM, Cowden JM, Scales JT, editors. Bedsore biomechanics. Baltimore: University Park Pr; 1976. p 301-10.

22. Sprigle S. Effects of forces and the selection of support surfaces. Top Geriatr Rehabil 2000;16:47-62.

23. Landis EM. Micro-injection studies of capillary blood pressure in human skin. Heart 1930;15:209-28.

24. Harstall C. Clinical effectiveness of commercially available interface pressure measurement systems for the prevention and management of pressure sores in wheelchair bound or bedridden persons. Can J Rehabil 1998;12:25-32.

25. Bader DL, Hawken MB. Pressure distribution under the ischium of normal subjects. J Biomed Eng 1986;8:353-7.

26. Ferguson-Pell M, Cardi MW, Hurwitz DE. Expert systems, a promising tool for patient assessment. In: Paul JP, Barbenel JC, Courtney JM, Kenedi RM, editors. Progress in bioengineering; 
proceedings of an international seminar held on the occasion of the 25th anniversary of the Strathclyde Bioengineering Unit, Glasgow, September 1988. Bristol: Adam Hilger; 1989. p 68-72.

27. Geyer MJ, Brienza DM, Karg P, Kelsey SF, Trefler E. Are commercial seat cushions efficacious in preventing pressure ulcers in the at-risk elderly nursing home population? In: Winters J, editor. Proceedings of RESNA Annual Conference; 2000 June 28-July 2; Orlando (FL). Arlington: RESNA Press; 2000. p 36971.

28. Ferguson-Pell M, Cardi M. Pressure mapping systems. Team Rehabil Rep 1992;Oct:28-32.

29. Ferguson-Pell M, Cardi M. Prototype development and comparative evaluation of wheelchair pressure mapping systems. Assistive Technol 1993;5:78-91.

30. Ranalli NC, Moynahan JB. Use of a pressure mapping system for problem identification and seating intervention. In: Sprigle S, editor. Proceedings of RESNA Annual Conference; 1997 June 20-24; Pittsburgh PA. Arlington (VA): RESNA Press; 1997. p $219-22$.

31. Garber SL, Krouskop TA. Body build and its relationship to pressure distribution in the seated wheelchair patient. Arch Phys Med Rehabil 1982;63:17-20.

32. Hobson DA. Comparative effects of posture on pressure and shear at the body-seat interface. J Rehabil Res 1992;29:21-31.

33. Vidal J, Sarrias M. An analysis of the diverse factors concerned with the development of pressure sores in spinal cord injured patients. Paraplegia 1991;29:261-7.
34. Shields RK, Cook TM. Effect of seat angle and lumbar support on seated buttock pressure. Phys Ther 1988;68:1682-6.

35. Shaw CG. Seat cushion comparison for nursing home wheelchair users. Assistive Technol 1993;5:92-105.

36. Takechi H, Tokuhiro A. Evaluation of wheelchair cushions by means of pressure distribution mapping. Acta Med Okayama 1998;52:245-54.

37. Sprigle SH, Faisant TE, Chung KC. Clinical evaluation of customcontoured cushions for the spinal cord injured. Arch Phys Med Rehabil 1990;71:655-8.

38. National Institute for Clinical Excellence. Inherited Clinical Guideline B. Pressure ulcer risk assessment and prevention. London: NICE; 2001. p 12.

39. Dreyfuss $H$. The measure of man. Human factors in design. 2nd ed. New York: Whitney Library of Design; 1967. p 13.

40. Stinson M, Porter A, Eakin P. Measuring interface pressure: a laboratory-based investigation into the effects of repositioning and sitting. Am J Occup Ther 2002;56:185-90.

41. Clark M, Rowland LB. Comparison of contact pressures measured at the sacrum of young and elderly subjects. J Biomed Eng $1989 ; 11: 197-9$

\section{Suppliers}

a. Vista Medical Ltd, 3-55 Henlow Bay, Winnipeg, Man R3Y 1G4 Canada.

b. SPSS Inc, 233 S Wacker Dr, 11th FI, Chicago, IL 60606. 